\title{
Calcium antagonist induced vasodilation in peripheral, coronary and cerebral vasculature as important factors in the treatment of elderly hypertensives
}

\author{
P. Erne, D. Conen, W. Kiowski, P. Bolli, F. B. Müller and F. R. Bühler \\ Division of Cardiology, Department of Medicine, University Hospital, 4031 Basel, Switzerland
}

KEY WORDS: Calcium antagonists, cerebral vasodilation, coronary vasodilation, essential hypertension, intracellular calcium, peripheral vasodilation, platelets.

Increased arteriolar tone is the pathophysiological hallmark of essential hypertension and is determined by the intracellular free calcium concentration in the vascular smooth muscle cell. Calcium influx is an important determinant of vasoconstriction and excess calcium influx-dependent vasoconstriction has been shown by plethysmographical studies in patients with essential hypertension.

Calcium antagonists acutely lower BP by reducing calcium influx, calcium concentration and peripheral resistance. The degree of the attendant sympathetic nerve reflex activation and counter-regulatory mechanisms determines the antihypertensive response of the individual. Chronic monotherapy with a calcium antagonist results in an antihypertensive response, which is directly related to the patient's age and pretreatment $B P$ and indirectly related to plasma renin levels. The resulting reduction in after-load neither leads to reduced cerebral blood flow in hypertensive patients, nor aggravates congestive heart failure.

Calcium antagonists are a useful alternative to diuretics, primarily in older patients with low renin levels, either alone or combined with any other antihypertensive drug, and provide effective and safe control of blood pressure.

\section{Introduction}

The major haemodynamic alteration in chronic essential hypertension is an increase in systemic resistance produced by the increased tone of arteriolar smooth muscle ${ }^{[1-4]}$. Vascular smooth muscle is dependent on calcium ion influx for the activation of contraction. The intracellular free calcium concentration has a pivotal role in determining vasoconstriction as the bridging between actin and myosin depends on the free intracellular calcium ion concentration $^{[1,2.5]}$. Factors that increase cytosolic calcium cause vasoconstriction and increase vascular tone, whereas factors that lower it cause vasodilation. The sources of cytosolic calcium may be either extracellular, that is, provided by calcium influx, or intracellular, from storage sites ${ }^{[-7]}$. Reduction of the free calcium concentration results from the action of an

Address for correspondence: Professor Fritz R. Bühler, Division of Cardiology, University Hospital, $\mathrm{CH}-4031$ Basel. Switzerland.
ATP-dependent calcium-sodium exchange pump process causing calcium extrusion from the cell, thus promoting vasodilation ${ }^{[3-5.7]}$. Regulation of calcium influx seems to be the major action of calcium antagonists; less significant effects are reduction of intracellular calcium binding mechanisms and the activation of calcium extrusion ${ }^{|1-7|}$.

\section{Platelet calcium-linked abnormalities in essential hypertension}

Platelets have been used to study calciumdependent processes in patients with essential hypertension. Platelets have the advantage of clinical accessibility and cellular homogeneity and might provide a model for vascular smooth muscle through a number of common morphological and functional features $^{[8]}$. These include:

(1) the possession of a number of receptors in common, for example, receptors for 5HT, prostaglandins 
and vasopressin, and alpha ${ }_{2}$ adrenoceptors, the latter being linked to an adenylate cyclase system which, when inhibited, results in vasodilation of smooth muscle and inhibition of platelet activation ${ }^{[9-10]}$;

(2) the possession of a calcium-dependent contractile protein coupling system ${ }^{[11.12]}$;

(3) the intimate relationship between the physiological changes of platelets and those of smooth muscle; for example, the release of thromboxane by platelets leads to vasoconstriction, whereas the release of prostacyclin by smooth muscle inhibits platelet activation $^{[3.14]}$.

An elevated free calcium concentration in platelets from patients with essential hypertension has been demonstrated in a number of studies, as summarized in Table 1. Figure 1 shows the correlation between the intracellular free calcium concentration and systolic and diastolic blood pressure (BP). Following antihypertensive therapy with calcium antagonists, beta-blockers or diuretics, the elevated free calcium concentration can be normalized ${ }^{15.20]}$, but an increased sensitivity to adrenaline which triggers a rise in free calcium by other hormones remains unaltered ${ }^{[21]}$. Increased calcium influx, as well as blunted extrusion mechanisms due to altered calciumATPase activity occur ${ }^{[22,23]}$ and may contribute to the elevated free calcium concentration in the platelets of patients with essential hypertension.

The complex pattern of altered platelet function in patients with essential hypertension suggests a causative underlying membrane pathology. In support of this hypothesis is the recent demonstration of an altered interconversion equilibrium of the phosphoinositides directed towards polyphosphoinositide formation and, therefore, to enhanced intracellular calcium release ${ }^{|22|}$.

Several vasodilators, and calcium antagonists in general, are inhibitory to platelet activation both in vitro and in vivo ${ }^{[24.25]}$. This, together with the altered platelet function of patients with essential hypertension, points to an altered calcium handling of hypertensive platelets. Although the calcium channel is genetically one of the oldest cellular membrane structures in eukaryocytes ${ }^{[26]}$, its long-lasting development could result in different characteristics in various cell types. Therefore, using the platelet as a model for the investigation of altered calcium influx in essential hypertension could have some limitations; whether the above-mentioned cellular modifications and possible membrane abnormalities also apply to smooth muscle cells has yet to be determined.

\section{Enhanced calcium influx-dependent vasoconstriction} in esssential hypertension

Direct measurements of the function of vascular smooth cells in hypertension are needed. For this purpose we used venous occlusion plethysmography and intra-arterial blood pressure recording to monitor forearm blood flow and vascular resistance ${ }^{[27]}$.

To determine if enhanced slow channel calcium influx-dependent vasoconstriction forms part of the pathophysiological mechanism in essential hypertension, the vasodilatory response of the regional vascular bed of the forearm to calcium antagonists was compared to alpha-1 and alpha-2 adrenoceptor blocking drugs as well as vasodilator probes which do not seem to involve slow channel calcium influx, for example, nitrates. A dose-dependent and enhanced calcium influx antagonistic vasodilator response was found in hypertensive patients for different calcium antagonists, such as for the dihydropyridine calcium antagonists, nifedipine, nitrendipine and nicardipine, as well as for the non-dihydropyridine calcium antagonist, verapamil|28] in agreement with those found by Robinson et al. ${ }^{[27]}$. The magnitude of vasodilation by the different calcium antagonists was comparable when applied at a maximal locally effective concentration avoiding systemic effects ${ }^{[28]}$. Comparison with other compounds showed that calcium influx-dependent vasodilation following calcium antagonists is similar to the vasodilatory response to post-ischaemic reperfusion and is about four times greater than that occurring in response to alpha- 1 or alpha- 2 blockade, and three times greater than the response to sodium nitroprusside ${ }^{[29]}$. There are a number of reports that calcium antagonists act by calcium influx inhibition as well as by interactions with the calcium pool and calcium extrusion from the cell ${ }^{[1.3-5.7]}$. Whatever the molecular basis for enhanced slow channel calcium influx, the data of forearm vasodilation show that enhanced calcium influx is a key contributing factor for the development of vascular hypertension responsiveness.

\section{Counter-regulation co-determines the antihypertensive response}

Administration of a calcium antagonist reduces elevated BP by:

(1) reducing excess calcium-influx dependent vasoconstriction;

(2) reflexly increasing baroreflex-mediated sympathetic nerve activity as shown by the transient rise 
Table 1 Details of studies which have demonstrated an elevated free calcium concentration in the platelets of patients with essential hypertension

\begin{tabular}{|c|c|c|c|c|c|}
\hline \multirow[t]{2}{*}{ Study } & \multicolumn{2}{|l|}{ Blood pressure } & \multicolumn{2}{|c|}{ Intracellular calcium (nM) } & \multirow[t]{2}{*}{ Comments } \\
\hline & Normotensives & Hypertensives & Normotensives & Hypertensives & \\
\hline Erne et al. ${ }^{[15]}$ & $124 / 79$ & $170 / 108$ & $108(N=30)$ & $168(N=23)$ & $P<0.01$ \\
\hline Bruschi et al. ${ }^{[16]}$ & & $176 / 114$ & $127(N=16)$ & $145(N=16)$ & $P<0.05$ \\
\hline Le Quan Sang et al. ${ }^{[17]}$ & 94 (mean BP) & 129 (mean BP) & $202(N=27)$ & $254(N=34)$ & $\begin{array}{l}P<0.01, \text { after } \\
\text { re-exposure to } \\
\text { extracellular calcium }\end{array}$ \\
\hline Lechi et al. ${ }^{\mid 18]}$ & & & $121(N=12)$ & $136(N=12)$ & $P<0.05$ \\
\hline Ashley et al..$^{[19]}$ & & & & & $\begin{array}{l}\text { Correlation between } \\
\text { calcium and diastolic } \\
\text { BP : r }=0.55 \\
P<0.05(N=16)\end{array}$ \\
\hline $\begin{array}{l}\text { Erne et al. } \\
\quad \text { (this study) }\end{array}$ & $120 / 76$ & $179 / 108$ & & & $\begin{array}{l}\text { Correlation between } \\
\text { calcium and diastolic } \\
\mathrm{BP}: \mathrm{r}=0.83, P<0.01 \\
(N=273, \text { including } \\
\text { borderline hypertensives) }\end{array}$ \\
\hline
\end{tabular}

in plasma noradrenaline and plasma renin activity which occurs acutely, but not chronically, with nifedipine $^{[30]}$.

Verapamil and diltiazem have a similar effect on sympathetic nerve activity, but the effect is less than that of the dihydropyridine calcium antagonists ${ }^{|31.32|}$. When the baroreflex is less active, as is commonly seen in older patients ${ }^{[32]}$, calcium antagonists produce a greater fall in $\mathrm{BP}^{[30]}$. These results suggest that the underlying cardiovascular counter-regulation of the individual patient co-determines the $\mathrm{BP}$ reduction, and is consistent with the observed reduction in baroreflex sensitivity and the blunted betaadrenoceptor mediated cardiac and renal responses in older patients and patients with more severe hypertension ${ }^{[34]}$. Therefore, in these situations larger reductions in $\mathrm{BP}$ can be expected for the same degree of vasodilation.
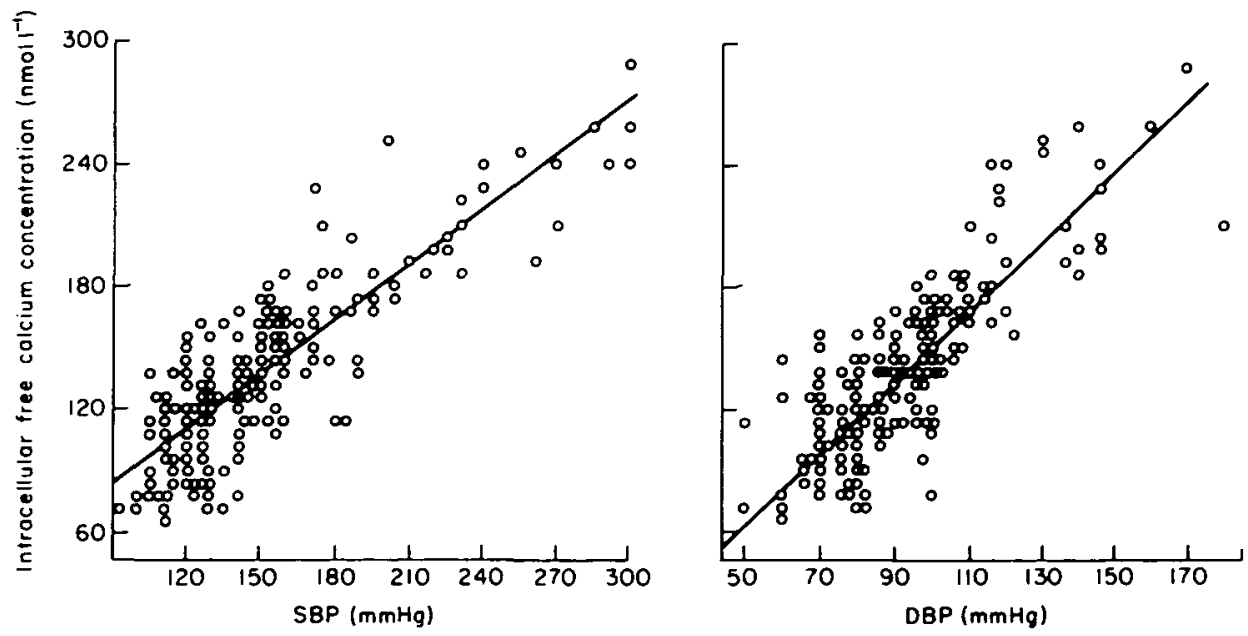

Figure 1 Correlation between intracellular free calcium concentration in human platelets and systolic (SBP) and diastolic (DBP) blood pressure. SBP: $r=0.847$, DBP: $r=0.836 ; P<0.001, N=273$, for both. Intracellular free calcium concentration was determined with the use of quin-2 as described elsewhere ${ }^{|15|}$. 


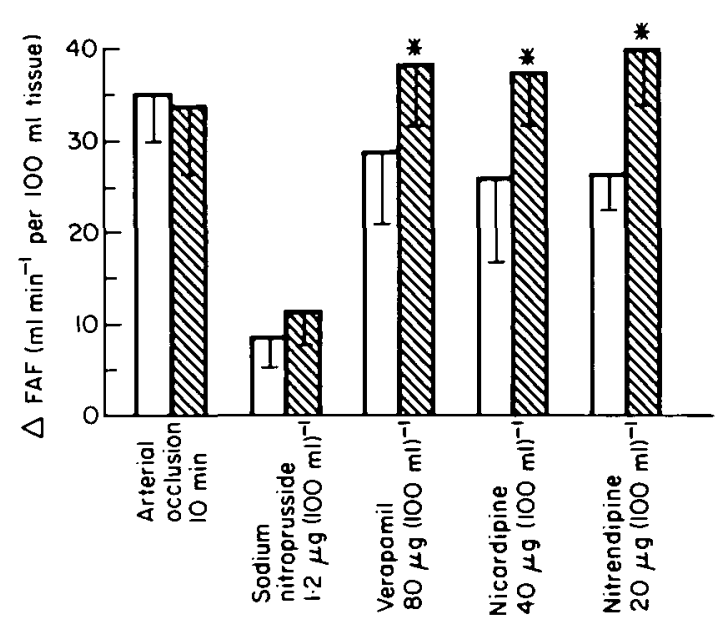

Figure 2 Increase in forearm blood flow $(\triangle F A F)$ in response during reperfusion following 10 minutes of forearm ischaemia and to an intra-arterial (brachial artery) infusion of sodium nitroprusside, verapamil, nicardipine or nitrendipine in 10 hypertensive $(\mathbb{\$})$ and 10 normotensive (口) subjects of comparable age and sex. ${ }^{*} P<0.01$.

\section{Antihypertensive treatment concept with calcium antagonists}

The pathophysiological mechanisms considered so far have been tested in several antihypertensive treatment studies with different types of calcium antagonist. The antihypertensive response has been found to be directly related to patient age and pretreatment BP and indirectly related to plasma renin activity (Fig. 3) ${ }^{[35.36]}$.

The age related efficacy of calcium antagonists is reciprocal to both that of beta-andrenoceptorblocking agents and angiotensin converting enzyme inhibitors $^{[37.38]}$. Thus, the diastolic BP of patients more than 60 years of age normalizes (i.e. $<95 \mathrm{~mm}$ $\mathrm{Hg}$, Korotkoff $\mathrm{V}$ ) in almost 4 times as many patients treated with a calcium antagonist than patients treated with a beta-blocker (Fig. 4), whereas the BP of patients less than 40 years of age normalizes in almost 4 times as many patients treated with betablocker monotherapy. Even in the $40-60$ year age group, an age trend emerges. A multivariate analysis has shown that $36 \%$ of the BP reduction can be accounted for by the age relationship, $31 \%$ by plasma renin activity and the remaining $33 \%$ by the pretreatment BP which is, to some extent, statistically linked to the drug-induced fall in $\mathrm{BP}^{(39)}$.

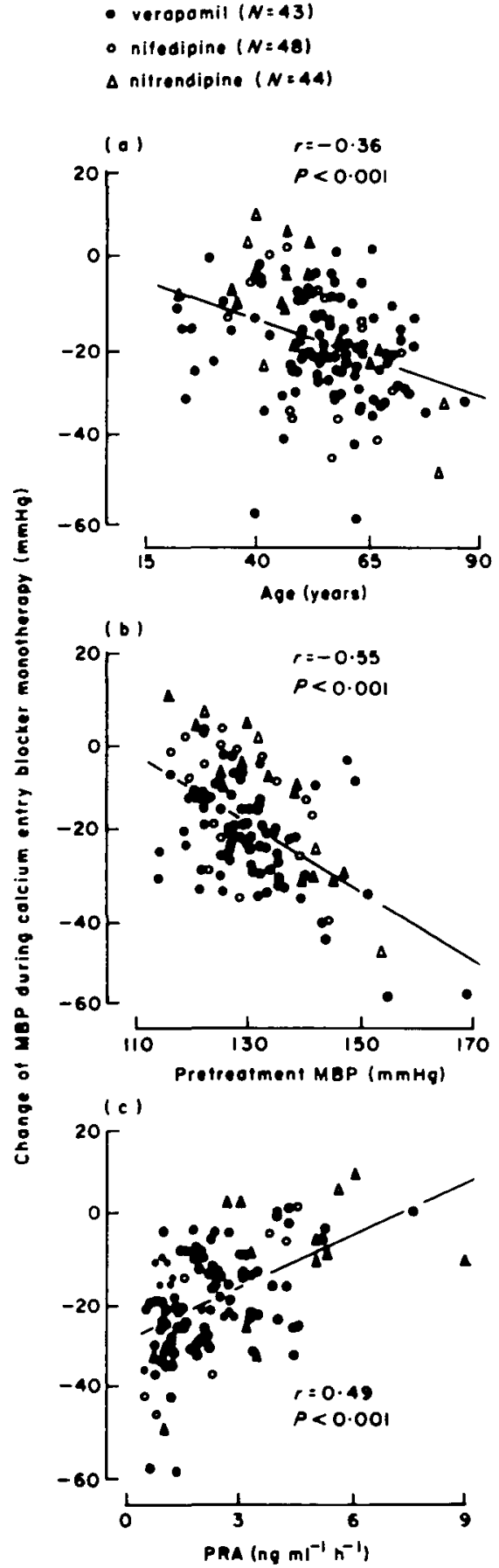

Figure 3 Changes of mean blood pressure (MBP) produced by calcium antagonist monotherapy were directly related to (a) patient age, (b) pretreatment blood pressure, and indirectly related to (c) pretreatment plasma renin activity (PRA). 


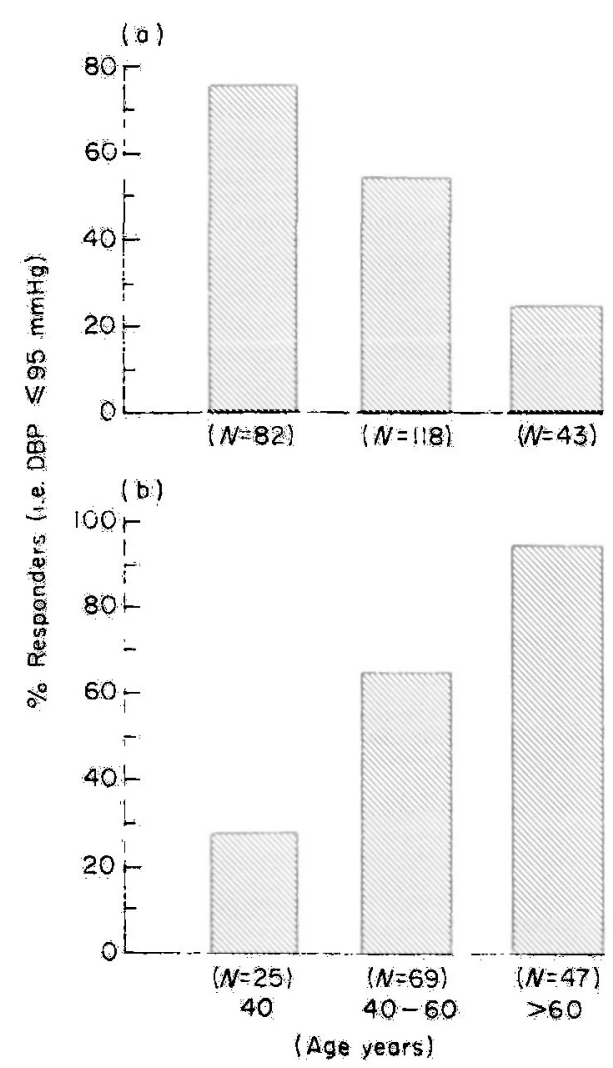

Figure 4 Patient age and response to antihypertensive monotherapy with (a) a beta-blocker, $n=243$; (b) a calcium antagonist, $n=141$.

\section{Comparison of calcium antagonists}

\section{ANTIHYPERTENSIVE EFFICACY}

Double-blind and open studies have found comparable antihypertensive effects with different calcium antagonists ${ }^{[36.411\}}$. In addition, the antihypertensive response pattern does not appear to be exclusive to a particular type of calcium antagonist, for in intraindividual comparisons of different calcium antagonists. including verapamil, diltiazem, nitrendipine and another 1,4-dihydropyridine, PN 200, similar antihypertensive responses were found. From the current evidence it appears that all available calcium antagonists have comparable antihypertensive efficacy in patients with mild to moderate hypertension.

Since calcium antagonists seem to act at different sites. further studies are needed to determine whether hypertension that is resistant to one calcium antagonist would respond to a different one, as suggested by a study comparing the effects of verapamil and nifedipine ${ }^{\mid+1 !}$. Until such data are available. the choice of drug for antihypertensive therapy is determined by the side-effects.

\section{SIDE-EFFECTS}

Major side-effects can be predicted from the pharmacological actions of the drug.

(1) Of the ealcium antagonists, nifedipine is one of the most potent vasodilators and so side-effects attributable to vasodilatation, such as headache, flushing and oedema, are more common with nifedipine than with verapamil or diltiazem ${ }^{[36,42]}$.

(2) All calcium antagonists have a negative inotropic effect in vitro, but this effect is minor in patients with normal cardiac function ${ }^{[6]}$.

(3) Verapamil and diltiazem have significant effects on cardiac conduction ${ }^{|6|}$. Although in most cases prolongation of atrioventricular conduction time is asymptomatic ${ }^{[43]}$, clinically significant disturbances have been reported, including higher forms of atrioventricular block ${ }^{[4]}$. Thus, if combinations of calcium antagonists and beta-blockers have to be used, a dihydropyridine type is the calcium antagonist of choice.

(4) Verapamil has the largest effect on the gastrointestinal tract; therefore, constipation is more common with verapamil than with diltiazem or nifedipine $e^{|36,45|}$.

The slightly different patterns of side-effects of calcium antagonists can determine the calcium antagonist used for combination therapy. Although verapamil has been safely combined with betablockers to treat patients with ischaemic heart disease and there are few cardiodepressant effects when they are combined in patients with normal cardiac function ${ }^{[46.47]}$. caution must be observed in patients taking verapamil or diltiazem with beta-blockers. On the other hand. nisoldipine and nifedipine have no apparent negative effect on myocardial contractility or atrioventricular conduction in vivo in therapeutic doses. and the current literature indicates that they can be safely combined with beta-blockers and other adrenergic inhibitors ${ }^{|18|}$. With respect to the need for combination therapy. antihypertensive response and tolerability, there is a great potential for the combination of calcium antagonists with angiotensin converting enzyme inhibitors ${ }^{[49]}$. Combinations of different calcium antagonists should be considered with caution because of their different binding structure at the same calcium channel ${ }^{[5(t)}$ which means that the combined inhibitory effects on calcium influx cannot. therefore, be preducted safely ${ }^{|s i|}$ until there are reports of controlled studies. 


\section{Effects of calcium antagonists on coronary and cerebral blood flow}

Clinical studies have demonstrated the antihypertensive efficacy of calcium antagonists in elderly hypertensive subjects. Calcium antagonists cause widespread arterial and arteriolar vasodilatation, but they vary in their ability to dilate different vascular beds. With respect to the safety of this therapy, therefore, special attention must be given to the effects of calcium antagonists on coronary and cerebral blood flow.

\section{CORONARY BLOOD FLOW}

The effects of the calcium antagonist, nisoldipine, were investigated in 18 patients with congestive heart failure which was resistant to basic therapy, acutely and for 4 weeks after therapy. Both stroke volume and ejection fraction increased acutely, during exercise and chronically. The change in systemic vascular resistance correlated with the change in stroke volume. Following acute administration of nisoldipine in a subset of these patients, coronary blood flow determined by continuous thermodilution ${ }^{|52|}$ increased by $25 \%$, at rest and during exercise ${ }^{|48|}$.

\section{CEREBRAL BLOOD FLOW}

The cerebral blood flow is usually maintained within narrow limits over a wide range of $\mathrm{BP}^{[53]}$. In essential hypertension, this autoregulation of cerebral blood flow is adapted to the height of the BP and this explains the possible cerebral deterioration during rapid and rigorous normalization of BP by antihypertensive treatment. While investigation of the acute effects of nifedipine in humans, or after shortterm therapy with nimodipine in an animal study, showed an increase of cerebral blood flow ${ }^{[54.55]}$, no change of cerebral blood flow was found in 10 patients with essential hypertension (age 50-67 years) following treatment with nitrendipine for 4 weeks (BP before nitrendipine, $165 \pm 16 / 106 \pm 5 v s$ $144 \pm 12 / 88 \pm 7 \mathrm{~mm} \mathrm{Hg}$ on nitrendipine; $P<0.001$; cerebral blood flow before nitridipine $51.5 \pm 7$ vs 50.8 $\pm 7.8 \mathrm{ml} 100 \mathrm{~g}^{-1} \mathrm{~min}^{-1}$ on nitrendipine; an insignificant difference ${ }^{[56]}$. These differences between acute or short term, and long-term effects are probably due to an increase of cerebral blood flow induced by activation of sympathetic activity and enhanced baroreflex sensitivity following the acute administration of calcium antagonists ${ }^{[30]}$.

\section{Conclusion}

These results suggest that calcium antagonists can be administered safely under controlled conditions to elderly patients with or without congestive heart failure ${ }^{|57-59|}$. The contrasting pattern of antihypertensive efficacy observed with beta-blockers and angiotensin converting enzyme inhibitors on the one hand, and calcium antagonists and diuretics on the other, suggests that:

(1) the initial treatment for younger patients with high plasma renin activity might be a beta-blocker or a converting enzyme inhibitor;

(2) the initial treatment for older patients with low plasma renin activity might be a calcium antagonist or a diuretic;

(3) a beta-blocker or a calcium antagonist may be used as the initial treatment for patients of $40-60$ years of age and for patients with a normal plasma renin activity.

This work has been supported by the Swiss National Fund Nr.3.807.080. P.E. was supported by the Swiss Foundationm for Biological and Medical Fellowships.

\section{References}

[1] Cohn JN. Calcium, vascular smooth muscle, and calcium entry blockers in hypertension. Ann Intern Med 1983; 98: 806-9.

[2] Bohr DF, Webb RC. Vascular smooth muscle function and its changes in hypertension. Am J Med 1984; 77 (Suppl 4A): 3-16.

[3] Van Breemen C, Lukeman S, Cauvin C. A theoretic consideration on the use of calcium antagonists in the treatment of hypertension. Am J Med 1984; 77 (Suppl 4A): $26-30$

[4] Rasmussen H. Cellular calcium metabolism. Ann Intern Med 1983; 98: 809-16.

[5] Braunwald E. Mechanism of action of calciumchannel-blocking agents. N Engl J Med 1982; 307: 1618-27.

[6] Henry PD. Comparative pharmacology of calcium antagonists: nifedipine, verapamil, and diltiazem. Am J Cardiol 1980; 46: 1047-58.

[7] Singh BN. An overview of slow calcium channel blocking drugs: pharmacologic basis for therapeutic applications. Cardiology 1982; 69: 2-25.

[8] Erne P, Resink TJ, Bürgisser E, Bühler FR. Platelets and hypertension. J Cardiovasc Pharmacol 1985; 7 (Suppl 6): S103-8.

[9] Erne P, Bühler FR, Affolter H, Bürgisser E. Excitatory and inhibitory modulation of intracellular free calcium in human platelets by hormones and drugs. Eur J Pharmacol 1983; 91: 331-2.

[10] Bolli P, Erne P, Kiowski W, Ji BH, Amann FW, Bühler FR. Important contribution of postjunctional alpha-2 adrenoceptor-mediated vasoconstriction to 
arteriolar tone in man. J Hypertension 1983; 1 (Suppl 2): 257-9.

[11] Niederman R, Pollard TD. Human platelet myosin. II. In vitro assembly and structure of myosin filaments. $\mathrm{J}$ Cell Biol 1975; 67: 72-92.

[12] Hinssen H, D'Haese J, Small JV, Sobieszek A. Mode of filament assembly of myosins from muscle and nonmuscle cells. J Ultrastr Res 1978; 64: 282-302.

[13] Moncada S, Gryglewski R, Bunting S, Vane JR. An enzyme isolated from arteries transforms prostaglandin endoper oxides to an unstable substance that inhibits platelet aggregation. Nature 1976; 263: 663-5.

[14] Robertson RM, Robertson D, Roberts LJ et al. Thromboxane $\mathrm{A}_{2}$ in vasotonic angina pectoris. $\mathrm{N}$ Engl J Med 1981; 304: 998-1003.

[15] Erne P, Bolli P, Bürgisser E, Bühler FR. Correlation of platelet calcium with blood pressure. Effect of antihypertensive therapy. N Engl J Med 1984; 310: 1084-8.

[16] Bruschi G, Bruschi ME, Caroppo M, Orlandini G, Spaggiari M, Cavatorta A. Cytoplasmic free $\left[\mathrm{Ca}^{2+}\right]$ is increased in the platelets of spontaneously hypertensive rats and essential hypertensive patients. Clin Sci 1985; 68: 179-84.

[17] Le Quan Sang KH, Montenay-Garestier T, Devynck MA. Platelet cytosolic free calcium concentration in essential hypertension. Nouv Rev Fr Hematol 1985; 27: 279-83.

[18] Lechi C, Bonadonna G, Polignano R, Arosio E, Covi $G$, Lechi A. Free calcium concentration in platelets of hypertensive patients. First international symposium on calcium and hypertension 1985; 1 .

[19] Ashley CC, Castell LM, Ledingham JGG et al. Relationships between lymphocyte and platelet intracellular free calcium concentrations, plasma-ionized calcium, and blood pressure in essential hypertension in humans. J Physiol (London) 1986; 372: 81P.

[20] Zidek W, Karoff C, Baumgart P, Losse H. Fehske, KJ, Vetter $H$. Intracellular sodium and calcium during antihypertensive treatment. Klin Wockenschr 1985, 63 (Suppl 3): 147-9.

[21] Erne P, Kiowski W, Resink TJ, Hefti A, Ritz R, Bühler FR. Hormonal modulation of intracellular free calcium in platelets from normotensive and hypertensive subjects. Klin Wochenschr 1985; 63 (Suppl III): 111-2.

[22] Resink TJ, Dimitrov D, Zschauer A, Erne P, Tkachuk VA, Bühler FR. Platelet calcium-linked abnormalities in essential hypertension. Ann NY Acad Sci (In press).

[23] Resink TJ, Tkachuk VA, Erne P, Bühler FR. Platelet membrane calmodulin-stimulated calcium adenosine triphosphatase. Altered activity in essential hypertension. Hypertension 1986; 8: 159-66.

[24] Erne P, Rogg H, Mittelholzer E, Resink TJ, Bühler FR. Effect of different vasodilators on cyclic nucleotides, calcium and shape change of the platelet. J Cardiovasc Pharmacol 1986; 8 (Suppl 8): 102-6.

[25] Johnson GJ, Leis LA, Francis GS. Disparate effects of the calcium-channel blockers, nifedipine and verapamil, on $\alpha_{2}$-adrenergic receptors and thromboxane $A_{2}$ induced aggregation of human platelets. Circulation 1986; 73: 847-54.

[26] Salkoff LB, Tanouye MA. Genetics of the ion channels. Physiol Rev 1986; 66: 301-29.

[27] Robinson BF, Dobbs RJ, Bayley S. Response of fore- arm resistance vessels to verapamil and sodium nitroprusside in normotensive and hypertensive men: evidence for a functional abnormality of vascular smooth muscle in primary hypertension. Clinic Sci $1982 ; 63: 33-42$.

[28] Hulthen UL, Bolli P. Amann FW, Kiowski W, Bühler FR. Enhanced vasodilation in essential hypertension by calcium channel blockade with verapamil. Hypertension 1982; 4 (3 pt II): 26-31.

[29] Bühler FR, Bolli P. Erne P et al. Adrenoceptors, calcium and vasoconstriction in normal and hypertensive man. J Cardiovasc Pharmacol 1985; 7 (Suppl 6): S 130-6.

[30] Kiowski W, Bertel O, Erne P et al. Hemodynamic and reflex responses to acute and chronic antihypertensive therapy with the calcium entry blocker nifedipine. Hypertension 1983; 5 (2 pt II): 170-4.

[31] Leonetti G, Cuspidi C, Sampieri L, Terzoli L, Zanchetti A. Comparison of cardiovascular, renal, and humoral effects of acute administration of two calcium channel blockers in normotensive and hypertensive subjects. J Cardiovasc Pharmacol 1982; 4 (Suppl 3): S319-24.

[32] Aoki K, Sato K, Kondo S, Yamamoto M. Hypotensive effects of diltiazem to normals and essential hypertensives. Eur J Clin Pharmacol 1983; 25: 475-80.

[33] Gribbin B, Pickering TG, Sleight P, Peto R. Effect of age and high blood pressure on baroreflex sensitivity in man. Circ Res 1971; 29: 424-31.

[34] Bühler FR. Age and cardiovascular response adaptation: determinants of an antihypertensive treatment concept primarily based on beta-blockers and calcium entry blockers. Hypertension 1983; 5 (5 pt II): III 94-100.

[35] MacGregor GA, Rottelar C, Markandu ND, Smith SJ, Sangella GA. Contrasting effects of nifedipine, captopril, and propanolol in normotensive and hypertensive subjects. J Cardiovasc Pharmacol 1982; 4 (Suppl 3): S 358-62.

[36] Erne P, Bolli P, Bertel O, Hulthen UL, Kiowski W, Bühler FR. Factors influencing the hypotensive effect of calcium antagonists. Hypertension 1983; 5: 97-102.

[37] Lijnen P, M'Buyamba JR, Fagard R, Staessen J, Amery A. Age related hypotensive response to captopril in hypertensive patients. J Hypertension (in press).

[38] Bühler FR, Burkart F, Lütold BE, Küng M, Marbet G. Pfisterer $M$. Antihypertensive betablocking action as related to renin and age: a pharmacological tool to identify pathogenetic mechanisms in essential hypertension. Am J Cardiol 1975; 36: 653-69.

[39] Gill JS, Zezulka AV, Beevers DG, Davies P. Relation between initial blood pressure and its fall with treatment. Lancet 1985 ; i: $567-9$.

[40] Klein W, Brandt D, Vrecko K, Härringer M. Role of calcium antagonists in the treatment of essential hypertension. Circ Res 1983; 52 (S 1): 174-81.

[41] Midtbo K, Hals O, von der Meer J. Verapamil compared with nifedipine in the treatment of essential hypertension. J Cardiovasc Pharmacol 1982; 4 (Suppl 3): $363-8$.

[42] Johnson SM, Mauritson DR, Willerson JT, Hillis LD. Comparison of verapamil and nifedipine in the treatment of variant angina pectoris: Preliminary observations in 10 patients. Am J Cardiol 1981; 47: 1295-300. 
[43] Halperin AK, Gross KM, Rogers JF, Cubeddu LX. Verapamil and propranolol in essential hypertension. Clin Pharmacol Ther 1984; 36: 750-8.

[44] Mitchell LB, Schroeder JS, Mason JW. Comparative clinical electrophysiologic effects of diltiazem. verapamil and nifedipine: A review. Am J Cardiol 1982; 49: 629-35.

[45] Krebs R. Adverse reactions with calcium antagonists. Hypertension 1983; 5 (S II): II-125-9.

[46] Subramanian B, Bowles MJ, Davies AB, Raftery EB. Combined therapy with verapamil and propranolol in chronic stable angina. Am J Cardiol 1982; 49: 125-32.

[47] Bonow RO, Leon MB, Rosing DR et al. Effects of verapamil and propranolol on left ventricular systolic function and diastolic filling in patients with coronary artery disease: radionuclide angiographic studies at rest and during exercise. Circulation 1982; 65: 133750 .

[48] Kiowski W, Erne P, Pfisterer M, Müller J, Bühler FR. Burkart R. Arterial vasodilator: systemic and hemodynamic effect of the calcium antagonist nisoldipine in congestive heart failure secondary to ischemic or dilated cardiomyopathy. Am J Cardiol 1987; 59: 111825.

[49] Brouwer RM, Bolli P, Erne P, Conen D, Kiowski W. Bühler FR. Antihypertensive treatment using calcium antagonists in combination with captopril rather than diuretics. J Cardiovasc Pharmacol 1985; 7 (Suppl): S 88-91.

[50] Striessnig J, Goll A, Moosburger K, Glossmann H. Purified calcium channels have three allosterically coupled drug receptors. FEBS Lett 1986; 197: 204-10.
[51] Godfraind T, Morel N, Wibo M. The heterogeneity of calcium movements in cardiac and vascular smooth muscle cells. Scand J Clin Lab Invest 1986; 46 (S 180): 29-39.

[52] Baim DS, Rothman MT, Harrison DC. Improved catheter for regional coronary sinus flow and metabolic studies. Am J Cardiol 1980; 46: 997-1000.

[53] Strandgaard S. Autoregulation of cerebral blood flow in hypertensive patients. Circulation 1976; 53: 720-7.

[54] Bertel O, Conen D, Radü EW, Müller J. Lang C. Dubach UC. Nifedipine in hypertensive emergencies. Br Med J 1983; 286: 19-21.

[55] McCalden TA, Nath RG, Thiele K. The effects of a calcium antagonist (nimodipine) on basal cerebral blood flow and reactivity to various agonists. Stroke 1984; 15: 527-30.

[56] Conen D, Gerber A, Orfei R, Müller J. Long-term therapy with nitrendipine: effect on cerebral blood flow in elderly hypertensive patients. J Cardiovasc Pharmacol 1987; 10 (Suppl): (in press).

[57] Given BD, Lee TH, Stone PH, Dzau VJ. Nifedipine in severely hypertensive patients with congestive heart failure and preserved ventricular systolic function. Arch Intern Med 1985, 145: 281-5.

[58] Schwartz AB. Chatterjee K. Vasodiolator therapy in chronic congestive heart failure. Drugs 1983; 26 : 148-73

[59] Timmis AD. Smyth P. Kenny JF, Campbell S, Jewitt DE. Effects of vasodilator treatment with felodipine on haemodynamic responses to treadmill exercise in congestive heart failure. $\mathrm{Br}$ Heart J 1984; 52: 314-20. 